University of Nebraska - Lincoln

DigitalCommons@University of Nebraska - Lincoln

$4-12-2017$

\title{
Vegetation response to invasive Tamarix control in southwestern U.S. rivers: a collaborative study including 416 sites
}

Eduardo Gonzalez

Anna A. Sher

Robert M. Anderson

Robin F. Bay

Daniel W. Bean

See next page for additional authors

Follow this and additional works at: https://digitalcommons.unl.edu/usgsstaffpub

Part of the Geology Commons, Oceanography and Atmospheric Sciences and Meteorology Commons, Other Earth Sciences Commons, and the Other Environmental Sciences Commons

This Article is brought to you for free and open access by the US Geological Survey at DigitalCommons@University of Nebraska - Lincoln. It has been accepted for inclusion in USGS Staff -- Published Research by an authorized administrator of DigitalCommons@University of Nebraska - Lincoln. 


\section{Authors}

Eduardo Gonzalez, Anna A. Sher, Robert M. Anderson, Robin F. Bay, Daniel W. Bean, Gabriel J. Bissonnete, Berenger Bourgeois, David J. Cooper, Kara Dohrenwend, Kim D. Eichhorst, Hishma El Waer, Deborah K. Kennard, Rebecca Harms-Weissinger, Annie L. Henry, Lori J. Makarick, Steven M. Ostoja, Lindsay V. Reynolds, W. Wright Robinson, and Patrick B. Shafroth 


\title{
Vegetation response to invasive Tamarix control in southwestern U.S. rivers: a collaborative study including 416 sites
}

\author{
Eduardo González, ${ }^{1,2}$ Anna A. Sher,,${ }^{2,18}$ Robert M. Anderson, ${ }^{2}$ Robin F. Bay, ${ }^{2}$ \\ Daniel W. Bean, ${ }^{3}$ Gabriel J. Bissonnete, ${ }^{4}$ Bérenger Bourgeois, ${ }^{5,6}$ David J. Cooper, ${ }^{7}$ \\ Kara Dohrenwend, ${ }^{8}$ Kim D. Eichhorst, ${ }^{9}$ Hisham El Waer, ${ }^{2}$ Deborah K. Kennard, ${ }^{10}$ \\ Rebecca Harms-Weissinger, ${ }^{11}$ Annie L. Henry, ${ }^{2}$ Lori J. Makarick, ${ }^{12,17}$ Steven M. Ostoja, ${ }^{13}$ \\ Lindsay V. Reynolds, ${ }^{14}$ W. Wright Robinson, ${ }^{15}$ and Patrick B. Shafroth ${ }^{16}$ \\ ${ }^{1}$ EcoLab (Laboratoire Ecologie Fonctionnelle et Environnement), CNRS, INPT, UPS, Université de Toulouse, \\ 118 Route de Narbonne Bâtiment 4R1, 31062 Toulouse Cedex 9, France \\ ${ }^{2}$ Department of Biological Sciences, University of Denver, F. W. Olin Hall, 2190 E Iliff Avenue, Denver, Colorado 80208 USA \\ ${ }^{3}$ Colorado Department of Agriculture, Biological Pest Control, Palisade Insectary, 75037.8 Road, Palisade, Colorado 81526 USA \\ ${ }^{4}$ U.S. Bureau of Land Management, 82 East Dogwood, Moab, Utah 84532 USA \\ ${ }^{5}$ Département de Phytologie, Faculté des Sciences de l'Agriculture et de l'Alimentation, Université Laval, \\ 2425 rue de l'agriculture, Quebec City, Quebec G1V0A6 Canada \\ ${ }^{6}$ Department of Biology, Québec Centre for Biodiversity Science, Mc Gill University, Stewart Biology Building, \\ 1205 Dr. Penfield Avenue, Montreal, Quebec H3A 1 B1 Canada \\ ${ }^{7}$ Department of Forest and Rangeland Stewardship, Colorado State University, Fort Collins, Colorado 80523 USA \\ ${ }^{8}$ Rim to Rim Restoration, P.O. Box 297, Moab, Utah 84532 USA \\ ${ }^{9}$ Department of Biology, Bosque Ecosystem Monitoring Program (BEMP), University of New Mexico, \\ MSC 03 2020, Albuquerque, New Mexico 87131 USA \\ ${ }^{10}$ Department of Physical and Environmental Sciences, Colorado Mesa University, Grand Junction, Colorado 81501 USA \\ ${ }^{11}$ Northern Colorado Plateau Network, National Park Service, Moab, Utah 84532 USA \\ ${ }^{12}$ Grand Canyon National Park, 1824 S, Thompson Street, Suite 200, Flagstaff, Arizona 86001 USA \\ ${ }^{13}$ USDA California Climate Hub, Agricultural Research Service, University of California, Davis, California 95616 USA \\ ${ }^{14}$ Department of Biology, Colorado State University, Fort Collins, Colorado 80523 USA \\ ${ }^{15}$ Grand County Weed Department, 125 East Center Street, Moab, Utah 84532 USA \\ ${ }^{16}$ U.S. Geological Survey, Fort Collins Science Center, 2150 Centre Avenue, Building C, Fort Collins, Colorado 80526 USA
}

Abstract. Most studies assessing vegetation response following control of invasive Tamarix trees along southwestern U.S. rivers have been small in scale (e.g., river reach), or at a regional scale but with poor spatial-temporal replication, and most have not included testing the effects of a now widely used biological control. We monitored plant composition following Tamarix control along hydrologic, soil, and climatic gradients in 244 treated and 172 reference sites across six U.S. states. This represents the largest comprehensive assessment to date on the vegetation response to the four most common Tamarix control treatments. Biocontrol by a defoliating beetle (treatment 1) reduced the abundance of Tamarix less than active removal by mechanically using hand and chain-saws (2), heavy machinery (3) or burning (4). Tamarix abundance also decreased with lower temperatures, higher precipitation, and follow-up treatments for Tamarix resprouting. Native cover generally increased over time in active Tamarix removal sites, however, the increases observed were small and was not consistently increased by active revegetation. Overall, native cover was correlated to permanent stream flow, lower grazing pressure, lower soil salinity and temperatures, and higher precipitation. Species diversity also increased where Tamarix was removed. However, Tamarix treatments, especially those generating the highest disturbance (burning and heavy machinery), also often promoted secondary invasions of exotic forbs. The abundance of hydrophytic species was much lower in treated than in reference sites, suggesting that management of southwestern U.S. rivers has focused too much on weed control, overlooking restoration of fluvial processes that provide habitat for hydrophytic and floodplain vegetation. These results can help inform future management of Tamarix-infested rivers to restore hydrogeomorphic processes, increase native biodiversity and reduce abundance of noxious species.

Key words: Diorhabda; exotic species control; management of biological invasions; plant communities; saltcedar; tamarisk.

\footnotetext{
Manuscript received 7 October 2016; revised 21 February 2017; accepted 12 April 2017. Corresponding Editor: Éva E. Plaganyi.

${ }^{17}$ Present address: Natural Resource Stewardship and Science, 1201 Oakridge Drive, Suite 200, Fort Collins, Colorado 80525 USA.

${ }^{18}$ Corresponding Author. E-mail: anna.sher@du.edu
} 


\section{INTRODUCTION}

Invasive, shrubby trees of the genus Tamarix (tamarisk, saltcedar) have become the second-most dominant woody species along southwestern U.S. rivers since their introduction from Eurasia in the early 1800s for ornamental purposes, windbreaks, and erosion control of riverbanks (Di Tomaso 1998, Friedman et al. 2005). Although Tamarix was naturalized and spreading along some western U.S. rivers before the boom of civil engineering in the 20th century (Birken and Cooper 2006), its rapid expansion was partly facilitated by altered hydro-geomorphic regimes of rivers caused by dam regulation and exploitation of water resources (Stromberg et al. 2007, Merritt and Poff 2010). Once established, Tamarix can contribute further to riparian habitat degradation, for example by increasing salinity in soils (Merritt and Shafroth 2012, Ohrtman et al. 2012). By occupying floodplain habitats, Tamarix can alter relative abundances of native taxa of both plants and wildlife (Shafroth et al. 2005, Bateman et al. 2013a), and is characterized as both a passenger and driver of ecosystem change (Johnson 2013).

Controlling invasive Tamarix has been a major priority of river management at the local, state, and federal levels in the United States (Shafroth and Briggs 2008, Douglass et al. 2013). The main motivation for Tamarix control for decades was "water salvage," although numerous studies now indicate that significant, long-term, water salvage is unlikely to occur in most Tamarix control situations (Nagler et al. 2010, Cleverly 2013, Zavaleta 2013, McDonald et al. 2015). Although water salvage is still a commonly stated objective for Tamarix control, contemporary control efforts frequently have a more holistic goal of improving the ecological value of riparian systems (Shafroth et al. 2008, 2013, Sher 2013).

Decades of trials with a diversity of techniques to remove Tamarix stands have resulted in effective reductions of $>90 \%$ in Tamarix density and cover and even total eradication at many sites across the Colorado River and Middle Rio Grande catchments (Harms and Hiebert 2006, Bay and Sher 2008, Belote et al. 2010, Reynolds and Cooper 2011, Ostoja et al. 2014). These approaches have used burning, mechanical removal with heavy machinery, aerial application of herbicide, and a popular technique consisting of cutting the tree with hand or chain saws followed by herbicide application to the stump (cut-stump method). However, these traditional, active removal techniques are labor-intensive, costly, and difficult to apply in remote areas. Moreover, they often involve localized disturbance with soil compaction, root disturbance, trampling, and unintended removal of native vegetation (Hultine et al. 2010). Because of these limitations, the tamarisk leaf beetle Diorhabda spp., a biocontrol agent that could reduce Tamarix populations with no further human intervention, was released in 2001 (DeLoach et al. 2003).
Since their release on the Sevier River, near Delta in west central Utah, Diorhabda spp. have spread throughout most of the southwestern U.S. rivers where Tamarix is abundant (Tamarisk Coalition 2016). High mortalities and canopy dieback of Tamarix following multiple years of defoliation by the beetle have led to reductions in cover of $50-90 \%$ in some locations (e.g., Humboldt and Walker rivers [Pattison et al. 2011], Virgin River, Nevada [Bateman et al. 2013b, Nagler et al. 2014, Hultine et al. 2015], Colorado River, Colorado [Kennard et al. 2016]). However, the few assessments of the effectiveness of biocontrol in reducing Tamarix populations have been very small-scale analyses (but see Nagler et al. 2012) without paired sites where active removal was implemented. These sites showed extremely variable stand-level tree mortalities that ranged from $0 \%$ to $56 \%$ (Kennard et al. 2016) and little is known about the factors that explain this extreme variability (Hultine et al. 2015). Consequently, whether biocontrol represents an effective alternative to active removal remains an open question. Also, very little is known about how biocontrol interacts with active removal methods. For example, Drus et al. (2014) showed that fire is more detrimental to Tamarix in the presence of beetles. The effectiveness of beetles as a new, natural, follow-up measure to avoid Tamarix resprouting following mechanical removal remains largely unstudied.

Of particular importance for the management of Tamarix-infested ecosystems is not only assessing the efficacy of methods for Tamarix control, but also the effects of Tamarix removal on the recovery of plant communities. Vegetation established following Tamarix removal will strongly influence ecosystem functionality (e.g., preservation of biodiversity, erosion control, wildlife habitat, nutrient cycling, water use, flammability, etc.; Shafroth et al. 2008). The reduction of Tamarix cover often results in depauperate systems that remain poorly vegetated and are often invaded by noxious, exotic weeds (Harms and Hiebert 2006, Hultine et al. 2010, Ostoja et al. 2014). In better situations, native vegetation, usually not strictly riparian as the local hydrology is frequently not restored, may establish (Reynolds and Cooper 2011). But in general, only slight improvements in native species diversity, richness, and absolute cover have been observed, with contrasting results among functional groups (Harms and Hiebert 2006, Belote et al. 2010, Ostoja et al. 2014). Most studies of vegetation recovery have been at the stream reach scale, or when done regionally, poorly replicated in space and time. As a result, little is known about the factors controlling the responses of replacement vegetation following Tamarix removal or mortality. Some factors, like climate, may operate at very large spatial scales such as the river catchment (Harms and Hiebert 2006, Bay and Sher 2008). Moreover, to our knowledge, only two studies have reported plant community responses to biocontrol (Sher et al. 2015, Kennard et al. 2016). However, both of these studies were limited to western Colorado 
(one of the first places where biocontrol beetles were released), and thus their observations may have been driven by local factors and may not represent all rivers in the southwestern U.S. region. Follow-up measures, such as revegetation with native plants or chemical treatment of secondary invasions by noxious weeds, are usually part of Tamarix control projects but their effectiveness has also rarely been systematically assessed (but see Bay and Sher 2008, Sher et al. 2008).

For this collaborative study involving 16 research institutions, we compiled published and unpublished information and collected new data on vegetation and associated key environmental and management variables from 244 Tamarix control projects using the four most common treatments: biocontrol, and mechanical removal by cutting or heavy machinery, and burning. The goal was to compare the relative effectiveness of biocontrol and traditional active removal techniques to reduce Tamarix abundance and favor native riparian plant communities. This comparison was done at a large scale and with enough spatiotemporal replication that we could account for variability observed between sites in the field and reported in the literature. Key vegetation descriptors associated with common goals of Tamarix control were used including vascular plant species diversity, abundance of Tamarix, native and exotic (non-noxious and noxious) species abundance, and abundance of hydrophytic vegetation.

\section{Methods}

\section{Study sites}

Vegetation composition after Tamarix treatment was monitored in 244 sites on floodplains and riverbanks along the main channel and minor and major tributaries of two of the largest river catchments in the American West: the Colorado River and the Rio Grande (Fig. 1). The sites spanned $\sim 350,000 \mathrm{~km}^{2}$ across six U.S. states: Arizona, California, Colorado, Nevada, New Mexico, and Utah.

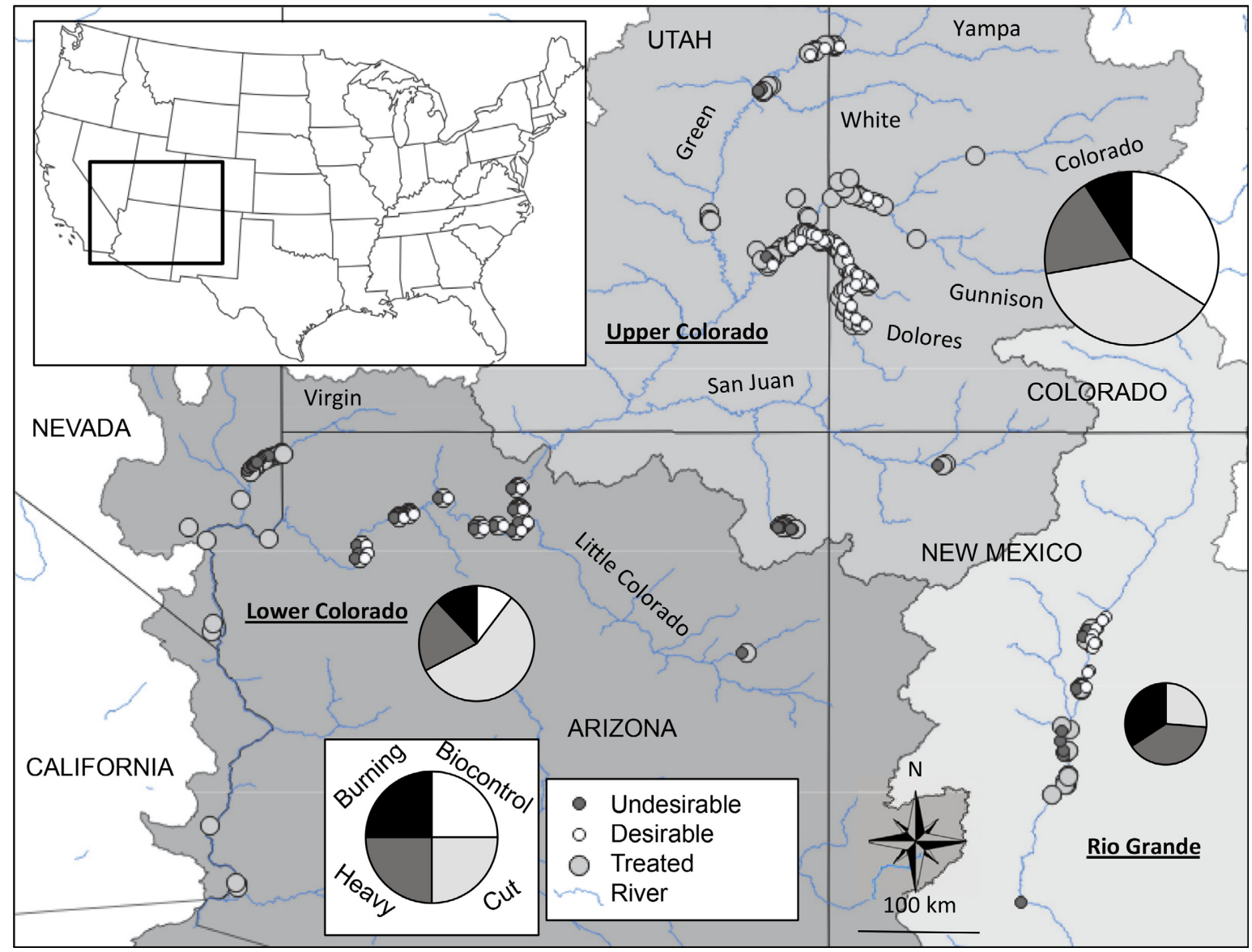

FIG. 1. Colorado and Rio Grande catchments showing locations of 244 sites, where invasive Tamarix has been treated either by active removal using burning, heavy machinery (heavy), hand or chain saws (cut), and by the action of the biocontrol agent, the Tamarix beetle (Diorhabda sp.); 79 undesirable sites, representing a starting point for Tamarix control; and 93 desirable sites, representing an optimal outcome. The size of the pie charts is proportional to the number of projects at each river catchment (Colorado, divided into upper and lower sub-catchments, and Rio Grande). Pie charts indicate the proportion of projects of each control type. [Color figure can be viewed at wileyonlinelibrary.com] 
For a site to be considered treated, it must have been subjected to control of Tamarix by at least one of the following four methods, in decreasing order of disturbance: prescribed or accidental burning of Tamarix stands ("burning"), mechanical removal using heavy machinery such as root plows, mowers, or bulldozers ("heavy machinery"), mechanical removal by chain or hand saws ("cut"), and action of the biocontrol agent, Diorhabda spp. ("biocontrol"). Sites that received more than one control method were placed into the category with the highest disturbance (i.e., burning $>$ heavy machinery $>$ cut $>$ biocontrol). Burning was considered as having the greatest disturbance because it affects both chemical and physical fluxes of nutrients in the ecosystem (Sher and Hyatt 1999). Follow-up treatments to limit Tamarix resprouting included (1) application of herbicide in any of three forms (aerial, from the ground, and (or) locally onto cut stumps), (2) root extraction (by default in all "heavy machinery" sites, and manually using a fixed pulley in the "cut" treatment), and (or) (3) defoliation by Tamarix beetles (by default when present in the area). Sites where aerial application of herbicide was the primary means of Tamarix control instead of a follow-up measure were not considered in this study because there were too few of this type for rigorous analysis. On-site burning of Tamarix stems and debris stacked in piles after removal was a common practice but not considered as a burning or secondary treatment. Although Tamarix was the focus of our study, the invasive tree Elaeagnus angustifolia (Russian olive) was also usually removed if found at the sites.

Tamarix treatments were sometimes completed with other follow-up measures such as active revegetation of native plants (usually pole planting or seeding) and (or) chemical treatment of other noxious species. The actions of these additional treatments could be applied simultaneously, later the same year, or in sequential steps over several years, but homogeneously across the entire site.

Data were also compiled for both undesirable (79) and desirable (93) reference sites. Both undesirable and desirable conditions were defined by each research institution within their independent research projects (Appendix S1: Table S1). However, undesirable and desirable reference sites across projects shared common characteristics. Undesirable sites included conditions that represented a starting point for treatments, either theoretically, i.e., a nearby site with an abundance of Tamarix (36 sites), or practically, i.e., the same site before Tamarix control (43 sites). The undesirable reference sites ranged from sparse, small, Tamarix individuals in the sub-canopy of a cottonwood forest to Tamarix monocultures. Desirable reference sites included both regularly flooded early successional communities and hydrologically disconnected areas in late stages of riparian succession, but all were dominated by native species and had low abundance of Tamarix (average of 3.7\% cover).

Each site, treated or reference, corresponded to a single geomorphic unit: a distinctive fluvial landform such as a gravel or sand bar, flood deposit, channel margin, abandoned channel, off-channel depression, floodplain terrace, etc., and was geo-referenced (latitude and longitude). Some sites were sampled in multiple years, making a total of 800 "observations" (i.e., a site sampled at a given year; Table 1). For the rare situation where more than one treatment was applied and the treatment applied later was a higher disturbance category than the first, we treated data collected at these different time points as if from separate sites. Likewise, pre-Tamarix treatment observations (43 sites, "practical" undesirable reference sites), were considered as separate sites from post-Tamarix treatment observations for the purpose of analysis.

\section{Vegetation surveys}

Vegetation composition in the 416 sites (244 Tamarix treated sites, 79 undesirable reference and 93 desirable reference sites) was collected for all species at a site using measurements of cover, estimated visually in quadrats within larger rectangular or circular plots, or by the line intercept method along transects (Appendix S1: Table S1). We will collectively refer to these values as

TABLE 1. Summary of sites and observations for treated, undesirable, and desirable reference sites.

\begin{tabular}{|c|c|c|c|c|c|c|c|}
\hline Parameter & $\begin{array}{l}\text { Biocontrol } \\
\text { only }\end{array}$ & Cut & $\begin{array}{l}\text { Heavy } \\
\text { machinery }\end{array}$ & Burning & $\begin{array}{l}\text { Undesirable } \\
\text { reference }\end{array}$ & $\begin{array}{l}\text { Desirable } \\
\text { reference }\end{array}$ & Total \\
\hline Total number of sites & 55 & 99 & 57 & 33 & 79 & 93 & 416 \\
\hline Total number of observations & 72 & 219 & 95 & 78 & 134 & 202 & 800 \\
\hline $\begin{array}{l}\text { Number of sites with only one observation } \\
\text { over time }\end{array}$ & 45 & 46 & 39 & 21 & 68 & 58 & 277 \\
\hline $\begin{array}{l}\text { Number of sites with two or more } \\
\text { observations over time }\end{array}$ & 10 & 53 & 18 & 12 & 11 & 35 & 139 \\
\hline $\begin{array}{l}\text { When two or more observations, median } \\
\text { number and range (in parenthesis) }\end{array}$ & $3(2-3)$ & $2(2-5)$ & $3(2-7)$ & $5(2-9)$ & $4(3-11)$ & $3(2-13)$ & $3(2-11)$ \\
\hline $\begin{array}{l}\text { Time (yr) since end of Tamarix removal (time } \\
\text { since beetle arrival at biocontrol only sites) } \\
\text { at the last observation, median (range) }\end{array}$ & $7(1-9)$ & $5(0-13)$ & $3.5(0-18)$ & $3(0-18)$ & NA & NA & NA \\
\hline
\end{tabular}

Note: NA indicates "not applicable." 
species cover or species abundance (\%), which are all given in absolute terms. Overlapping layers of vegetation within a single species were not considered in calculating species abundance (e.g., tree seedlings and mature individuals) such that the maximum value for one species at a given site was $100 \%$. The abundance of plant groups, for example of native species, however, could be higher than $100 \%$, as it resulted from the sum of species abundances that could overlap.

\section{Environmental variables}

We collected information on 15 environmental variables that could play a role in determining the plant community assemblies (Appendix S1: Table S2). Data for each environmental variable was collected for each site with the exception of grazing intensity, river metrics, and soil metric variables, which had some sites with missing information and thus were removed from analyses as needed (Table 2):

1. Grazing intensity. The intensity of grazing by livestock was registered on a four-point semi-quantitative scale based on interviews with land managers and visual assessments of grazing activities (e.g., density of excrements; 0 , none; 1 , light; 2 , moderate; 3 , severe).

2. Stream flow permanence. We noted if the stream flow was "permanent" or "intermittent" (with "ephemeral" merged in the latter category).

3-5. River metrics. Aerial pictures and absolute elevation data taken from Google Earth were used to calculate the river width (m), the shortest distance from the center of the site to the margin of the main channel (m), and the longitudinal slope (i.e., difference of elevation in the river from $500 \mathrm{~m}$ upstream from the site to $500 \mathrm{~m}$ downstream from the site, $\%$ ).

6-8. Soil metrics. Composite samples were taken from the soil surface to analyze salinity, $\mathrm{pH}$, and texture of the fine fraction $(<2 \mathrm{~mm})$. Soil salinity was determined as electrical conductivity of a saturated soil paste. $\mathrm{pH}$ was determined using a 1:1 water solution. Percentage of sand $(>63 \mu \mathrm{m})$ in the fine fraction was used as a surrogate of soil texture.

9-14. Climate metrics. Precipitation and temperature datasets were downloaded from the PRISM Climate Group website. ${ }^{19}$ For each site, we obtained six variables: precipitation, maximum and minimum monthly temperature during the growing season (April-September), averaged for a period of $30 \mathrm{yr}$ (normal 1971-2000 if sampling was done in 2005 or before; $1981-2010$ for 2006 or later), and for the year of survey.

\footnotetext{
${ }^{19} \mathrm{http}: / /$ prismmap.nacse.org/nn/
}

15. River valley shape. The river valley was analyzed from visual inspections of aerial photos and classified as "confined" (i.e., in a canyon) or "unconfined" (i.e., in a broad lowland area).

\section{Key vegetation descriptors}

As a first step, we calculated vegetation descriptors that best represented the most common goals in Tamarix control projects: reducing Tamarix, increasing the cover and diversity of native species, controlling secondary invasions of exotic species, and increasing cover of hydrophytic or riparian wetland-type vegetation (Shafroth et al. 2008). Hence, we calculated abundances of (1) Tamarix, (2) native species, (3) other exotic (nonnoxious and noxious) species, and (4) hydrophytic species for each treatment and type of reference site. The choice of these first four vegetation descriptors (1-4) was supported by a Principal Component Analysis (PCA) performed on Hellinger-transformed (Legendre and Gallagher 2001) species abundance that summarized the variability of plant communities on a few axes (principal components; Appendix S2). Other measures for each treatment and type of reference site included (5) Shannon's diversity index as a measure of alpha diversity and (6) beta diversity (sum of squared Hellinger's transformed distances of $n$ sites of the same category divided by $n \times[n-1])$ to represent heterogeneity. We used the U.S. Department of Agriculture PLANTS Database to determine the nativity, noxious, and hydrophytic character of all species (USDA-NRCS 2014; Data S1). An exotic species was noxious if that was its legal status in at least one of the six states where our study sites were located. Bassia scoparia (common kochia) was added to the list because it is listed as noxious species in other U.S. states and was one of the most abundant species in the database. Tamarix was not determined to the species level but all Tamarix species are exotic and classed as noxious in North America. Tamarix ramosissima, T. chinensis, and their hybrids are the most common in southwestern U.S. rivers (Gaskin 2013), and it is our understanding that these are the species included in this study. However, in all cases we did not include Tamarix in our calculations of non-noxious and noxious exotic species, which we considered as a separate category. Solanum elaeagnifolium is a native species but still considered noxious as it can poison livestock and can be invasive locally. Hydrophytic species are those that need saturated soil conditions and were defined as those with an obligate wetland (OBL, "almost always occur in wetlands") or facultative wetland (FACW, "usually occur in wetlands") designation in the PLANTS Database for the "Arid West" region (accessed on October 2014). We created the category of hydrophytic species to act as an indicator of low-lying, saturated areas of floodplains usually associated with more geomorphically active fluvial landforms in contrast to disconnected, higher, and drier floodplains (Corenblit et al. 2009, Merritt 2013). 


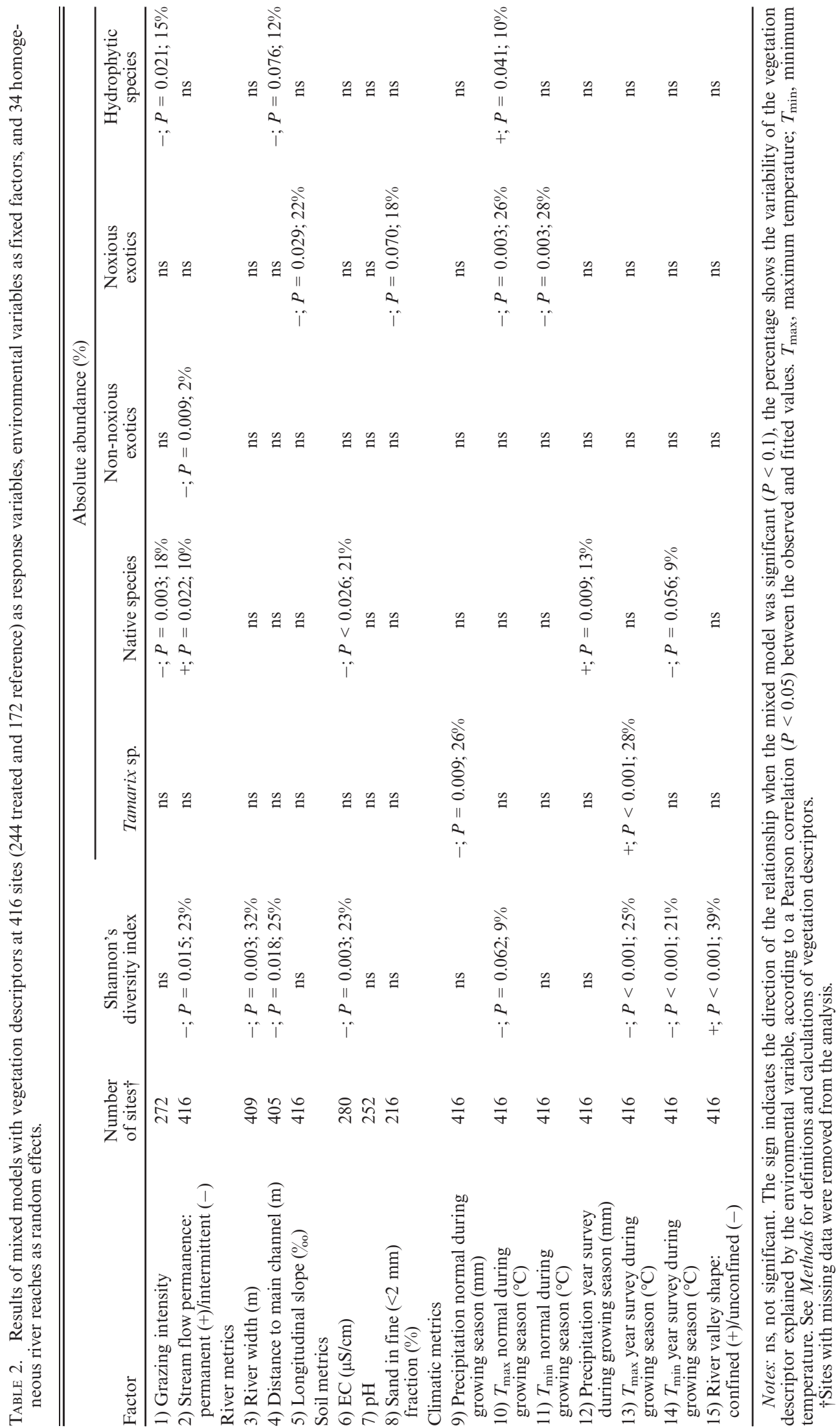




\section{Data analysis}

Initial effectiveness of removal methods.-We compared the key vegetation descriptors at the last observation (excluding beta-diversity) of each one of the four treatments between them and against the reference conditions using Mann-Whitney tests $(P<0.05)$ for all pairwise comparisons, after testing significant differences for the six categories using Kruskal-Wallis tests $(P<0.05$, not shown).

Change over time. - We used two approaches to explore vegetation changes over time. The first was to compare the first and last observation at each treatment and reference type using the 139 sites that were sampled multiple years (median 3-yr span, Table 1) for each of the key vegetation descriptors using nonparametric Wilcoxon matched pairs. Second, the effect of time since removal (time since arrival of beetles in biocontrol sites) on the four treatments was also explored using time-for-space substitutions (i.e., chronosequences, for up to $18 \mathrm{yr}$ since treatment) in mixed models, with key vegetation descriptors of the last observation at each site $(\log [x+1]$-transformed except for Shannon diversity) as dependent variables, time since removal as fixed effect and river reach as random effect.

Environmental gradients. - As some of the sites were pseudo-replicated, both temporally (i.e., some sites sampled several years, Table 1) and spatially (high spatial correlation in the vegetation and environmental variables as indicated in preliminary analyses using Asymmetric Eigenvector Maps, not shown), we used mixed models with location as a random variable to assess the independent role of environmental variables to explain key vegetation descriptors (excluding beta diversity, which was calculated for each site type). Key vegetation descriptors $(\log [x+1]$-transformed except for Shannon diversity) of the last observation at each site were the response variables. Explanatory variables were the 15 environmental data categories (fixed effects; Appendix S1: Table S2) with 34 homogeneous river reaches (as indicated by Asymmetric Eigenvector Maps, not shown) as a random effect. We ran the models for each vegetation descriptor and each environmental variable separately, while including all the 416 sites, as we were not interested in the specific response of each of the six site types (four treatments and two references) to the environmental conditions. Some models had $n<416$ where data on an environmental variable were not available for a small subset of sites (Table 2).

Effectiveness of follow-up actions. - Finally, we compared the effectiveness of the different follow-up strategies for treating Tamarix resprouts, promoting natives with revegetation (planting poles vs. seeding vs. not revegetation) and controlling secondary invasions (application of herbicide on noxious exotic species vs. not application) by using a battery of Mann-Whitney tests $(P<0.05)$ that compared the abundance of Tamarix, native species, and noxious exotic species at the last observations, respectively. For Tamarix resprouting, treatments were analyzed separately. For revegetation and control of secondary invasions, treatments were merged because of the small sample size.

All the analyses were done with the packages vegan (Oksanen et al. 2013) and nlme (Pinheiro et al. 2007) in R. 3.4.2 (R Core Team 2016), and SPSS 13.0 (SPSS Inc. Released 2005. SPSS for Windows, Version 16.0. Chicago (Illinois), SPSS Inc).

\section{RESUlTS}

A total of 606 taxa, 485 of which are native, were identified, 516 to the species level, on the 416 sites (Data S1). The total number of noxious species was 31 (excluding Tamarix spp.). A total of 87 taxa were defined as hydrophytic (i.e., OBL or FACW; USDA-NRCS 2014). "Cut" was the most frequent Tamarix control method (99 sites), followed by "heavy" (57), "biocontrol" (55), and "burning" (33) (Table 1). Burning and heavy machinery were more frequent than cutting in the Middle Rio Grande, while biocontrol was more frequent in the Upper Colorado, as beetles were released at several locations upstream from Lake Powell since 2001. Beetles were not released to the Lower Colorado downstream from Hoover Dam or to the Middle Rio Grande but naturally dispersed to those locations as of $\sim 2011$ (Tamarisk Coalition 2016; pie charts, Fig. 1).

\section{Effectiveness of removal methods}

The mean Shannon's diversity index of all sites was 1.62 and was lowest in undesirable, biocontrol, and burning and the highest in desirable sites and cut sites (alpha-diversity, Table 3). Sites where Tamarix was cut were also the most heterogeneous, as shown by betadiversity (Table 3). Shannon's diversity index increased when repeated observations over time were made in cut and desirable sites and along the chronosequences of biocontrol and burning sites (Table 3 ).

Tamarix abundance was greatly reduced by all treatments to levels found in desirable sites, but more so by the active removal methods (up to $90 \%$ reduction, burning, heavy, and cut) than by biocontrol only $(\sim 50 \%$ reduction; Fig. 2a). Total eradication occurred in $38 \%$ of the active removal projects (71 of 189), while in only $4 \%$ of the sites subjected to biocontrol only ( 2 of 55 ).

Native species increased over time in some but not all types of removal sites as determined by chronosequence analysis (biocontrol and burn sites) or the multiple observation analysis (cut sites, arrows in Fig. 2b). Native graminoids (i.e., grass and grass-like plants including sedges [Cyperaceae] and rushes [Juncaceae]; USDANRCS 2014) at the cutting (9.3\%) and heavy machinery $(13.1 \%)$ treatments doubled and almost tripled the cover found at undesirable condition sites $(4.7 \%)$, respectively 
(- main species: Carex spp. [sedges], Distichlis spicata [saltgrass], Muhlenbergia asperifolia [scratchgrass], and Sporobolus cryptandrus [sand dropseed]; Data S1). Native forbs (i.e., all non-graminoid herbs; USDANRCS 2014) did not show a great response to any treatment (main species: Isocoma acradenia [Alkali goldenbush], Anemopsis californica [yerba mansa]; the two not geographically widespread; Data S1). Yet despite these gains, mean native species abundance was not significantly different than undesirable reference sites in three of the treatment methods and, for burn sites, it was significantly less (Fig. 2b). However, this was partly due to a lower abundance of native shrubs and trees (Populus spp. [cottonwoods], Salix spp. [willows], Baccharis spp. [false willows], and Forestiera pubescens [New Mexican privet], being the most representative; Data S1) in all treatments other than heavy machinery (Mann-Whitney tests, not shown), and also because the mean number of years post removal was only five.

The abundance of non-noxious exotic species was very low $(<7 \%$ abundance, Fig. $2 \mathrm{c})$ at all site types, with graminoids (main species: Polypogon monspeliensis [annual rabbitsfoot grass], P. viridis [beardless rabbitsfoot grass]) and forbs being the most frequently present plant groups (main species: Melilotus alba [sweetclover] and Chenopodium album [lambsquarters]). Non-noxious exotic species decreased in the time series of undesirable sites.

Noxious weeds decreased in biocontrol sites but increased in cut sites, when observed over multiple years. Noxious exotic species, however, were much more abundant than non-noxious. Their highest absolute abundance occurred when applying the highest disturbance techniques (burning and, especially, heavy machinery), but this was mainly due to a $12 \times$ (burning) to $16 \times$ (heavy machinery) increase in abundance of noxious forbs (mainly Acroptilon repens [Russian knapweed], Bassia scoparia [common kochia], and Salsola tragus s.l. [Russian thistle]; Data S1; Fig. 2d). Noxious graminoids (mainly Bromus tectorum [cheatgrass], B. rubens [red brome], and B. diandrus [ripgut brome]; Data S1) kept the same cover or even decreased (e.g., from $8.4 \%$ in the undesirable conditions to $0.7 \%$ in the burning treatment). Noxious shrubs and trees other than Tamarix (mainly Elaeagnus angustifolia [Russian olive]; Data S1) were almost eradicated from the treated sites.

Desirable sites had a much higher abundance of hydrophytic species (Salix exigua [coyote willow], Phragmites australis [common reed], Phalaris arundinacea [reed canarygrass], Muhlenbergia asperifolia [scratchgrass], Carex sp. [sedges], and Pluchea sericea [arrowweed] being the most representative, in decreasing order of cover; Data S1) than all the other site types (hydrophytic species, Fig. 2e). Only a few hydrophytic species were exotic, but non-noxious and never dominating (Agrostis gigantea, Atriplex patula, Echinochloa crus-galli, and several species of Polygonum; Data S1). Over time, hydrophytic species only changed in burned sites (increasing along the chronosequence). 

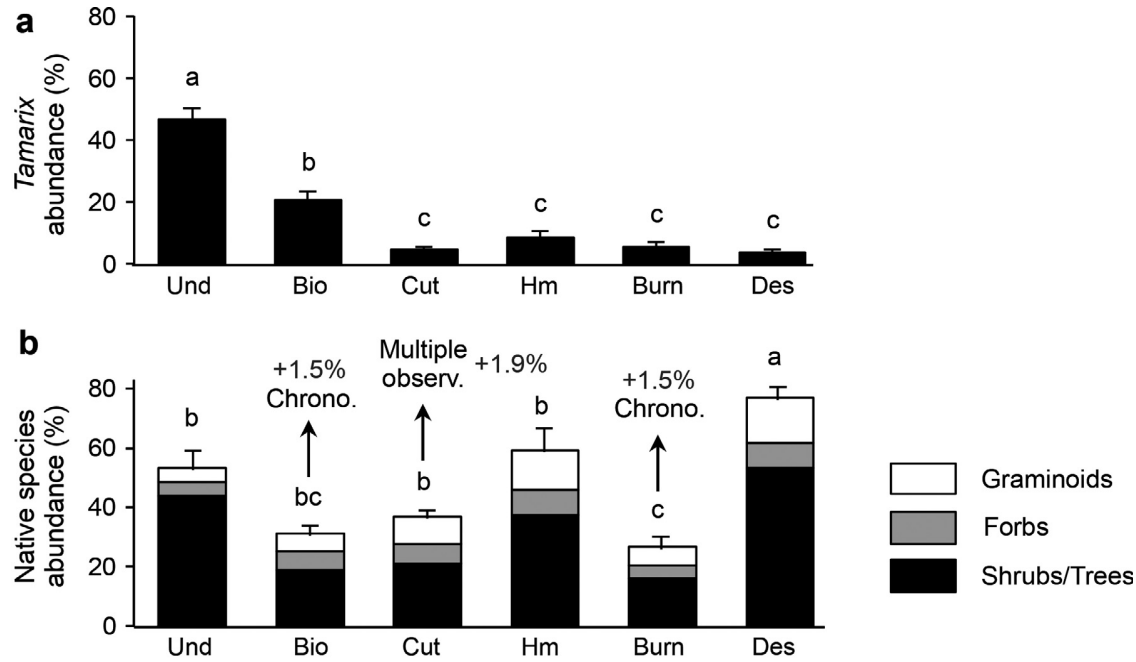

\section{C}
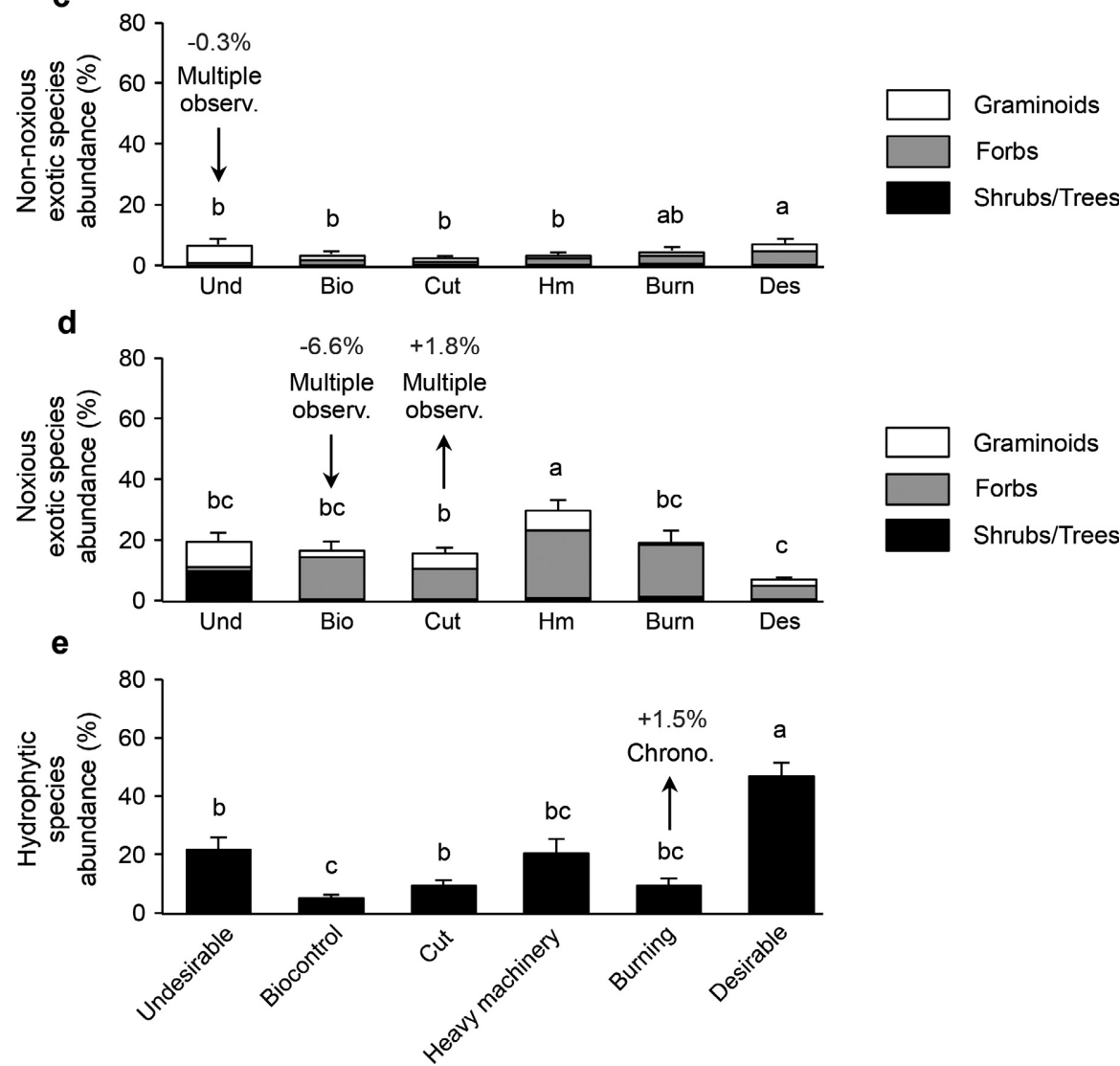

FIg. 2. (a) Tamarix, (b) native, (c) non-noxious exotic, (d) noxious exotic, and (e) hydrophytic species abundance (mean and $\mathrm{SE}$ ) in the treated, undesirable, and desirable reference sites, calculated from vegetation data collected at the last observation at each site. The same letters above bars indicate homogeneous groups after Mann-Whitney tests $(P<0.05)$. For each treatment, arrows pointing upward indicate an increase over time along repeated sampling in a subset of sites (Multiple observ., Wilcoxon tests; Table 1) or using space-for-time substitutions (Chrono., mixed models; $P<0.05$ ). Arrows pointing downwards indicate a temporal decrease. The numbers above the columns indicate the yearly percentage of increase or decrease, averaged per site. See Methods for definitions and calculations of plant groups. The $x$-axis abbreviations in panels a-d are spelled out in panel e. 

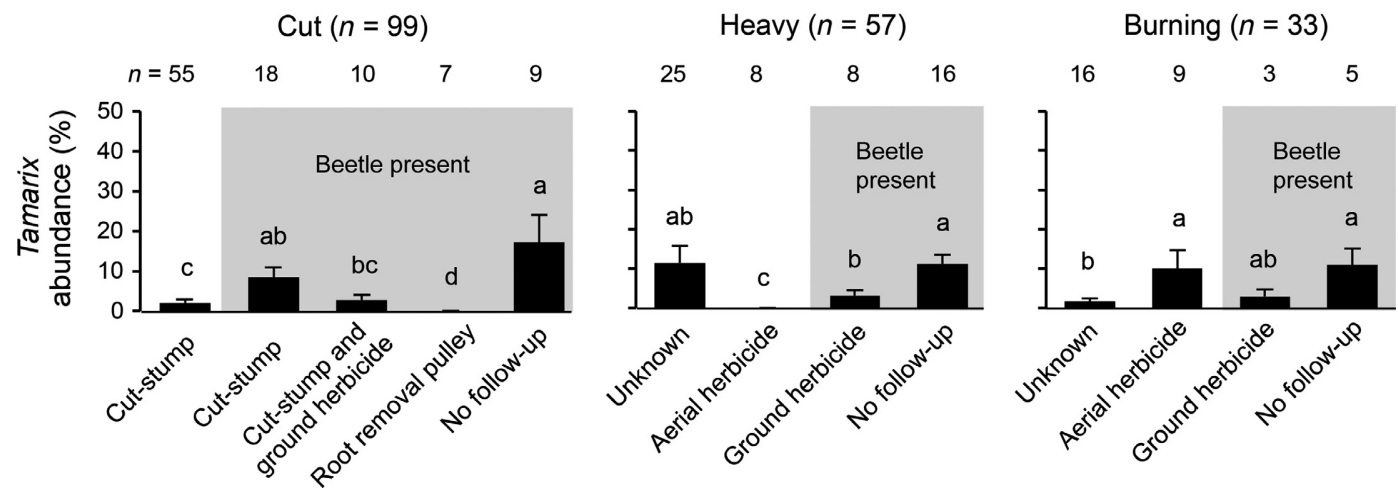

FIG. 3. Tamarix abundance (mean and SE) for several follow-up methods to limit Tamarix resprouting following three active methods of initial Tamarix removal (Cut, cut-stump method; Heavy, using heavy machinery; Burning, prescribed or accidental burning) at the last year of observation for each site. Bars with the same letters indicate homogeneous groups after Mann-Whitney tests $(P<0.05)$. There is no follow-up in the biocontrol treatment and therefore is not shown.

\section{Environmental gradients}

Overall, higher aridity represented by higher temperatures and lower precipitation, intermittent reaches, and higher soil salinity favored Tamarix cover over diversity and cover of both native and hydrophytic species (environmental gradients, Table 2). Noxious weeds were more commonly found at colder sites, and at low-energy reaches represented by a smaller percentage of sand in the fine soil fraction and lower longitudinal slopes.

\section{Effectiveness of follow-up actions}

Tamarix abundance differed more among follow-up strategies to limit Tamarix resprouting than among initial removal methods (i.e., cut, heavy machinery, burning) and, overall, the follow-up of Tamarix resprouting resulted in greater control than no follow-up. The manual removal of the whole individual by using a fixed pulley after cutting was remarkably successful, attaining local eradication (Cut, Fig. 3). The application of herbicide was especially effective after cutting (cut-stump method and herbicide spraying of resprouts from the ground; Cut, Fig. 3) and when using heavy machinery (especially if applied aerially), regardless of the beetle presence (Heavy, Fig. 3). However, the application of herbicide was not as important to limit resprouting in burning sites (Burning, Fig. 3). Revegetation, either by pole planting or seeding, did not result in a higher abundance of native species (Fig. 4). Similarly, application of herbicides on noxious weeds did not result in a lower abundance by these species (Fig. 5).

\section{Discussion}

Tamarix is more effectively reduced by active removal than by biocontrol

All methods used to control Tamarix invasion analyzed in this article reduced Tamarix abundance compared to that at undesirable reference conditions, often reaching local eradication when active removal (cut, heavy machinery, and burning) was carried out. This conclusion supports observations of $>90 \%$ decrease in Tamarix density and cover (Appendix S1: Table S1; Harms and Hiebert 2006, Belote et al. 2010, Reynolds and Cooper 2011, Ostoja et al. 2014). Our results also corroborate recent findings that although far from

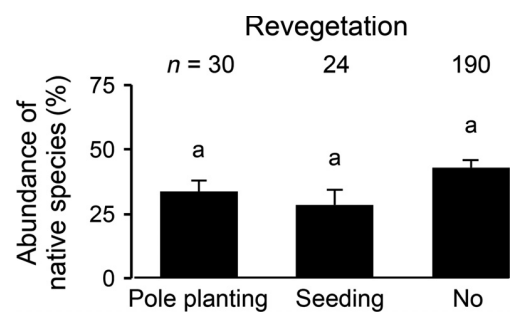

FIG. 4. Abundance of native species (mean and SE) for two revegetation methods: pole planting, mostly cottonwood (30 sites), and seeding of native plants mixtures (24 sites), at the last year of observation for each site. "No" means no revegetation (190 sites). Bars with the same letters indicate homogeneous groups after Mann-Whitney tests $(P<0.05)$.

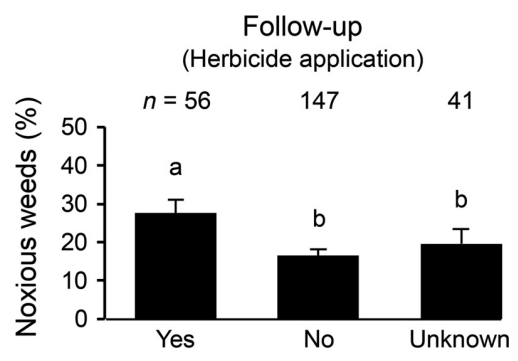

FIG. 5. Abundance of noxious weeds (mean and SE) after chemical treatment aiming at controlling secondary invasions (Yes, 56 sites), at the last year of observation for each site. No, no chemical treatment on noxious weeds (147 sites); Unknown, no information available on chemical treatment on noxious weeds (41 sites). Bars with same letters indicate homogeneous groups after Mann-Whitney tests $(P<0.05)$. 
eradication and less effective than active removal methods, biocontrol has reduced Tamarix cover by at least $50 \%$ in most regions in just one decade (Pattison et al. 2011, Hultine et al. 2015, Kennard et al. 2016).

The differences in Tamarix abundance between active removal treatments and biocontrol did not decrease over time with repeated defoliations by the beetles. In fact, we did not find any significant changes in Tamarix abundance in the sites repeatedly sampled over time nor in the chronosequences of any of the four treatments. For the active removal treatments, being discrete in time, we interpret the lack of changes over time as a result of follow-up actions being effective in controlling resprouting. For biocontrol, other studies showed that the bulk of defoliation normally occurs during the first few years after the arrival of beetles and stabilizes afterwards (Hultine et al. 2010, Kennard et al. 2016). Given that initial beetle introduction to most of our biocontrol sites occurred up to $4 \mathrm{yr}$ prior to sampling, it is possible that the most dramatic defoliation periods are not represented in our data set. Regardless of the limitations of the experimental design in detecting temporal changes, time may be less important than initially expected in explaining differences in Tamarix cover between treatments at such a large spatial scale. Hultine et al. (2015) suggested that defoliation-induced canopy dieback in Tamarix could be more dependent on abiotic and biotic factors operating across broad spatial gradients than to the number of defoliation events (expressed as time since arrival of beetles in our study) that ranged from two to seven in their study. Consistent with Hultine et al. (2015), we found that environmental gradients reflecting climatic aridity and follow-up strategies to limit resprouting had a greater power in explaining Tamarix abundance than the number of defoliations. McShane et al. (2015) also found that higher temperatures were associated with a greater abundance of Tamarix at a continental scale.

\section{Native species benefit slightly from all methods of Tamarix control}

The effective removal and defoliation of Tamarix led to an enhancement of native plant species but only to a small degree (by a range of $1.5 \%$, biocontrol and burning, to $1.9 \%$, cut yearly). Thus given the short amount of time elapsed since removal in most of the sites, we observed no significant difference overall in native cover between treatment sites and untreated reference sites. Consistent with published results (Harms and Hiebert 2006, Belote et al. 2010, Reynolds and Cooper 2011, Ostoja et al. 2014; Appendix S1: Table S1), we found higher diversity of natives and a slightly higher abundance of native graminoids in the cutting and heavy machinery treatments. These results suggest that Tamarix decline released natives from competitive pressure, for example, native graminoid growth may have been stimulated by increased light, but it is important to note that this has not translated into dramatically more successful establishment and growth of native species.

Several reasons may underlie this. First, most sites were surveyed fewer than 5 yr post Tamarix removal; previous research suggests that significant plant community recovery may not be detected until $7 \mathrm{yr}$ or more have elapsed (Bay and Sher 2008). Also, as suggested by Ostoja et al. (2014), disturbance created during Tamarix control, especially by methods with high disturbance, may have removed native species as well as exotics, for example, Salix gooddingii confused with Elaeagnus angustifolia (K. Eichhorst, personal field observations) and, by burying and damaging the seed banks, reduced the capacity of new native individuals to colonize the restored sites. In fact, our data suggest that native woody plant abundance may have decreased following Tamarix removal, even though this may also be an artifact caused by not having pre-removal data for most of the treated sites. Second, treatment of Tamarix does not necessarily exert any positive influence on many of the abiotic factors identified in our study as drivers of natives (e.g., atmospheric precipitation is not affected by Tamarix removal) and might have had a negative or uncertain influence on others. For example, loss of Tamarix cover may lead to excessive temperatures and higher evaporation in soils (Sher et al. 2008), and therefore higher soil salinity (Ohrtman et al. 2012) and may also represent an easier access to the sites by grazing livestock (Sher 2013), all situations seeming to disfavor natives (Rowland et al. 2004). Other legacies of long-term Tamarix domination may have limited reestablishment of natives. For example, chemical components in the soils may inhibit germination (e.g., salt accumulation; Ohrtman et al. 2012, Merritt and Shafroth 2012); and impoverished microbial communities may hamper growth and performance of native plants (Corbin and D'Antonio 2012). Poorer than expected recovery of native plant communities has been also reported in other riparian systems following removal of exotic trees, which may have reduced ecosystem resilience after decades of invasion (e.g., Acacia and Eucalyptus spp. in riparian areas of the South African Fynbos Biome [Blanchard and Holmes 2008], Ligustrum sinense [Chinese privet] in the Oconee River, Georgia, USA [Hudson et al. 2014]). Finally, as we believed was the case for Tamarix abundance, environmental gradients might be outweighing the effects of time in explaining differences in abundance of native species between sites at the large spatial scale considered in this study.

Perhaps surprisingly, active revegetation did not result in a higher cover by native species. This could simply reflect the fact that the most degraded sites were the most likely to be actively revegetated. Other possibilities include: high mortality of planted poles of cottonwoods in regulated floodplains, especially when access to groundwater is not guaranteed (Briggs et al. 1994, Stromberg 2001), sown seeds may not germinate in sufficient numbers (Dela Cruz et al. 2014), density of plants 
established as a result of revegetation is too low to strongly influence the plant community (Orr and Koenig 2006), or that the positive effects of active plant introduction are only visible at long time frames. Bourgeois et al. (2016), for example, showed that planted trees in riparian buffer strips only have an effect on the understory layer after 12-13 yr, when they develop a sufficiently dense canopy to shade out light demanding species. Bay and Sher (2008) detected an age threshold of $9 \mathrm{yr}$ for improved cover by planted species and also showed that local hydrology and climatic factors were very important to revegetation success. Limiting grazing, improving access to groundwater, and selecting species adapted to local climatic and environmental constraints could improve the outcomes of revegetation and promote a faster recovery and dominance of native species (Briggs et al. 1994, Shafroth et al. 2008).

Tamarix control may induce secondary invasions of noxious forbs, especially following high treatment-related disturbance

While the peak of available resources following Tamarix decline was not fully exploited by native species, noxious exotic species frequently increased in abundance, especially if removal was done using high disturbance methods such as heavy machinery and burning. These observations would support the hypothesis that disturbance in a broad sense can induce plant invasions (Hobbs and Huenneke 1992, Sher and Hyatt 1999, Davis et al. 2000, Kreyling et al. 2008). Similar findings have been reported in riparian zones of other world regions. For example, a poor recovery of the native plant community, followed by secondary invasions of noxious weeds after removal of invasive Acacia and Eucalyptus spp. by burning occurred in South African riparian systems (Blanchard and Holmes 2008). However, Tamarix control did not affect all functional groups of noxious exotics equally. Graminoids (mainly annual Bromus spp.) were the most abundant noxious exotics in undesirable reference conditions, and did not increase after human intervention, even decreasing in the burning treatment. Dela Cruz et al. (2014) showed that burning was an effective treatment to control invasive Bromus spp. in riparian zones of the Virgin River in Zion National Park (Utah, USA). Noxious shrubs and trees, notably E. angustifolia, were rarely found in the treated sites, despite being abundant in Tamarix-infested sites, as they were generally removed in all treatments but biocontrol.

The three most aggressive secondary invasions were caused by noxious exotic forb species. Two of them, Bassia scoparia and Salsola tragus plants, are tumbleweeds, prolific seed producers having efficient windmediated seed dispersal (Baker et al. 2008, Friesen et al. 2009). They may be greatly favored by the opening of safe sites for recruitment that immediately follows soil disturbance and removal of competing vegetation caused by heavy machinery or burning. The third most frequent noxious weed, Acroptilon repens, is a perennial, persistent forb that can expand vigorously by spreading rhizomes, especially following openings in the canopy layer as it is a light-demanding species (Jacobs and Denny 2006, Sherry et al. 2016).

Surprisingly, secondary invasions worsened over time in the cutting treatment and declined only in the 10 biocontrol sites repeatedly monitored over time. The conditions that caused site degradation and Tamarix infestation may persist after removal and continuously favor weeds, which have functional traits typical of ruderal and stress-tolerant strategies, similarly to Tamarix (Glenn and Nagler 2005). For example, Tamarix sites usually lack mycorrhizal fungi and most weed species are non-mycorrhizal species (Shafroth et al. 2008). Another reason to explain the persistence of noxious weeds over time is that floodplains and river banks are inherently high disturbance systems, often leading to weedy plant invasions (Planty-Tabacchi et al. 1996, Richardson et al. 2007). Long-term monitoring of the treated sites is suggested to assess whether more time will reverse the observed trends (Pearson et al. 2016).

Also unexpectedly, noxious weeds were more abundant in sites where herbicides were applied on herbaceous (non-tamarisk) weeds as part of follow-up treatments. As was the case for revegetation follow-up, a higher abundance of weeds following herbicide application could simply result from herbicides being only applied when noxious weeds had colonized the sites. Unfortunately, other limitations in the database hampered further investigation: for example, before-after information on follow-up measures to control secondary invasions was only available for eight sites, and repeated observations over time once herbicides were applied existed for 16 sites only (with no significant decrease of weeds over time, Wilcoxon test between first and last observation, $P<0.05)$. Limitations of the database notwithstanding, herbicides may also be less effective than initially intended. Species such as B. scoparia and S. tragus, for example, have developed resistance to commonly used herbicides such as imazapyr and glyphosate, hampering their reduction and eradication (Primiani et al. 1990, Chodova and Mikulka 2000, Shafroth et al. 2013). Herbicides may also negatively affect germination of native species (Dela Cruz et al. 2014, Douglass et al. 2016).

\section{Treatments provided no significant enhancement of fluvial processes represented by the abundance of hydrophytic species}

Many reaches and tributaries of both the Colorado River and Rio Grande are highly regulated by dams and levees (Merritt and Poff 2010). With flooding-related disturbance and channel migration severely limited, key fluvial processes such as erosion and sedimentation, necessary to create the heterogeneity of habitats typical of healthy riparian zones and floodplains, are severely impaired (Merritt and Cooper 2000, Johnson 2002, Graf 
2006). Regulated floodplains tend to experience vertical and lateral accretion of sediments or channelization and down-cutting, both of which can lead to disconnecting the river from its former floodplain and a resulting "terrestrialization" of plant communities (i.e., replacement of riparian and wetland with dryland species; Johnson 2002, Dixon et al. 2012, Reynolds et al. 2013). Tamarix removal and defoliation did not seem to enhance erosion and rejuvenation of fluvial landforms, which would have presumably been colonized by hydrophytic species with more preference for shallow groundwater and saturated soils, typical of early stages of riparian succession (Corenblit et al. 2009, Merritt 2013). Jaeger and Wohl (2011) reported that stream channels in the Canyon de Chelly National Monument (Arizona) kept an entrenched morphology following Tamarix and Russian olive removal. There, Reynolds and Cooper (2011) noted that the species that recolonized the sites cleared of Tamarix were mainly upland species, not early successional riparian. Conversely, Vincent et al. (2009) reported extensive erosion and channel widening following Tamarix removal in a small stream of New Mexico (Rio Puerco), but did not look at the colonizing vegetation that resulted from those processes.

In our study, all treatments and undesirable reference sites had a much lower abundance of hydrophytic species compared to desirable sites. Overbank flooding and channel morphology was only improved in a few study sites as part of the control works (e.g., lowering floodplain at "Crawford" site; Rio Grande, Eichhorst K, Appendix S1: Table S1) or responded spontaneously as a result of Tamarix removal (e.g., enhancement of sandbar erosion at sites located in Dinosaur National Monument; Green River, González E, Appendix S1: Table S1). There, hydrophytic species were responsive to restoration of local fluvial processes and dominated the treated sites.

Furthermore, reductions in Tamarix cover without proportionally large increases in understory cover of all types have broad ecological and environmental implications, including water use via evapotranspiration (Shafroth et al. 2005, Zavaleta 2013). Although significant water savings seems unlikely, recent research on the impacts of the biological control beetle suggest that reductions in evapotranspiration are, in fact occurring in the first few years following control (Pattison et al. 2011, Nagler et al. 2014, Sueki et al. 2015, Liebert et al. 2016). We detected much more dramatic reductions in Tamarix cover by active means, relative to biological control. Regardless, the extent of reduction in water use resulting from Tamarix control by any method is expected to be a function of local climate, water availability, the preexisting, and the replacement vegetation (Bloodworth et al. 2016). Because water use by hydrophytic native trees is comparable to that of Tamarix (Nagler et al. 2009, Cleverly 2013), if there is proportionally great recovery of those after Tamarix removal, it is unlikely that there will be water salvaged. However, the slow recovery of hydrophytic species we observed, in addition to the slow recovery of native plants in general, suggests that the dramatic decreases in Tamarix cover documented here should have some net reductions in evapotranspiration. This does not exclude the possibility that in the future, once full recovery of vegetation has occurred, water use returns to pre-Tamarix control levels. Removal of Tamarix also has important implications for wildlife; previous research has shown that some species benefit, while other birds, mammals, and herpetofauna that have come to use Tamarix are negatively affected (Bateman et al. 2013a). Native species replacement will mitigate most if not all negative effects, as native wildlife should have the capacity to return to using those plants and trees they have evolved with. However, the slow rate of recovery observed in this study suggests that at least in the short term we should expect some negative effects to wildlife.

Current Tamarix control projects rarely address the main causes of river degradation (Stromberg 2001, Sher 2013), and therefore the reactivation of fluvial processes leading to the rejuvenation of fluvial landforms, represented here by the establishment of hydrophytic vegetation, is not expected. Increasing site flooding may also be necessary to promote geomorphic change and germination of seeds of species that are not strictly hydrophytic, native species (Reynolds and Cooper 2011, Ostoja et al. 2014). However, both native and hydrophytic species were as (if not more) dependent on environmental gradients (e.g., grazing pressure, distance to water channel, climatic) as on Tamarix removal methods. Research has found that, if fluvial conditions are appropriate, native species are competitive with Tamarix without any direct intervention (Stromberg 1997, Sher et al. 2002, Sher and Marshall 2003). A comprehensive management approach for southwestern U.S. rivers that not only focuses on weed control but also on the restoration of the local fluvial processes is challenging in the context of growing human pressure on water resources and climate change (Stromberg 2001, Tockner and Stanford 2002, Palmer et al. 2008, Perry et al. 2015) but should be considered wherever possible.

\section{ACKNOWLEDGMENTS}

This research was supported by a Marie Curie International Outgoing Fellowship within the 7th European Community Framework Programme (ESFFORES project grant number 299044) and a National Science Foundation Dynamics of Coupled Natural and Human Systems award (project number 1617463). The authors also thank David Merritt and Cameron Douglass for willingness to share their data. Jennifer Schuetz provided valuable help to interpret BEMP's project data (Appendix S1: Table S1). Tamara Naumann and her staff in Dinosaur National Monument provided invaluable help sampling sites and providing very fruitful discussions. The work of the field assistants Stuart Coles, Michael Nagy and Rick Kluiver was also very much appreciated. We appreciate the comments of Catherine Jarnevich and Elisabeth Brouvers, which improved an earlier version of the manuscript. Any use of trade, firm, or product names is for descriptive purposes only and does not imply endorsement by the U.S. Government. 


\section{Literature Cited}

Baker, D. V., G. Beck, B. J. Bienkiewicz, and L. B. Bjostad. 2008. Forces necessary to initiate dispersal for three tumbleweeds. Invasive Plant Science and Management 1:59-65.

Bateman, H. L., P. L. Nagler, and E. P. Glenn. 2013b. Plot- and landscape-level changes in climate and vegetation following defoliation of exotic saltcedar (Tamarix sp.) from the biocontrol agent Diorhabda carinulata along a stream in the Mojave Desert (USA). Journal of Arid Environments 89:16-20.

Bateman, H., E. Paxton, and W. Longland. 2013a. Tamarix as wildlife habitat. Pages 168-188 in A. A. Sher, and M. Quigley, editors. Tamarix: a case study of ecological change in the American West. Oxford University Press, New York, New York, USA.

Bay, R. F., and A. A. Sher. 2008. Success of active revegetation after Tamarix removal in riparian ecosystems of the southwestern United States: a quantitative assessment of past restoration projects. Restoration Ecology 16:113-128.

Belote, R. T., L. J. Makarick, M. J. Kearsley, and C. L. Lauver. 2010. Tamarisk removal in Grand Canyon National Park: changing the native non-native relationship as a restoration goal. Ecological Restoration 28:449-459.

Birken, A. S., and D. J. Cooper. 2006. Processes of Tamarix invasion and floodplain development along the Lower Green River, Utah. Ecological Applications 16:1103-1120.

Blanchard, R., and P. M. Holmes. 2008. Riparian vegetation recovery after invasive alien tree clearance in the Fynbos Biome. South African Journal of Botany 74:421-431.

Bloodworth, B. R., P. B. Shafroth, A. A. Sher, R. B. Manners, D. W. Bean, M. J. Johnson, and O. Hinojosa-Huerta. 2016. Tamarisk beetle (Diorhabda spp.) in the Colorado River basin: synthesis of an expert panel forum. Colorado Mesa University, Colorado, USA.

Bourgeois, B., A. Vanasse, E. González, R. Andersen, and M. Poulin. 2016. Threshold dynamics in plant succession after tree planting in agricultural riparian zones. Journal of Applied Ecology 53:1704-1713.

Briggs, M. K., B. A. Roundy, and W. W. Shaw. 1994. Trial and error-assessing the effectiveness of riparian revegetation in Arizona. Restoration and Management Notes 12:160-167.

Chodova, D., and J. Mikulka. 2000. Identification of resistance to imazapyr and cross resistance to selected sulfonylurea herbicides in Kochia scoparia. Zeitschrift for Pflanzenkrankheiten und Pflanzenschutz 17:383-388.

Cleverly, J. R. 2013. Water use by Tamarix. Pages 85-98 in A. A. Sher, and M. F. Quigley, editors. Tamarix: a case study of ecological change in the American West. Oxford University Press, New York, New York, USA.

Corbin, J. D., and C. M. D'Antonio. 2012. Gone but not forgotten? Invasive plants' legacies on community and ecosystem properties. Invasive Plant Science and Management 5:117-124.

Corenblit, D., J. Steiger, A. M. Gurnell, E. Tabacchi, and L. Roques. 2009. Control of sediment dynamics by vegetation as a key function driving biogeomorphic succession within fluvial corridors. Earth Surface Processes and Landforms 34:1790-1810.

Davis, M. A., J. P. Grime, and K. Thompson. 2000. Fluctuating resources in plant communities: a general theory of invasibility. Journal of Ecology 88:528-534.

Dela Cruz, M. P., V. B. Beauchamp, P. B. Shafroth, C. Decker, and A. O'Neil. 2014. Adaptive restoration of river terrace vegetation through iterative experiments. Natural Areas Journal 34:475-487.

DeLoach, C. J., P. A. Lewis, J. C. Herr, R. I. Carruthers, J. L. Tracy, and J. Johnson. 2003. Host specificity of the leaf beetle,
Diorhabda elongata deserticola (Coleoptera: Chrysomelidae) from Asia, a biological control agent for saltcedars (Tamarix: Tamaricaceae) in the Western United States. Biological Control 27:117-147.

Di Tomaso, J. M. 1998. Impact, biology, and ecology of saltcedar (Tamarix spp.) in the Southwestern United States. Weed Technology 12:326-336.

Dixon, M. D., W. C. Johnson, M. L. Scott, D. E. Bowen, and L. A. Rabbe. 2012. Dynamics of plains cottonwood (Populus deltoides) forests and historical landscape change along unchannelized segments of the Missouri River, USA. Environmental Management 49:990-1008.

Douglass, C. H., S. J. Nissen, and C. H. Hart. 2013. Tamarisk management: lessons and techniques. Pages 333-353 in A. A. Sher and M. F. Quigley, editors. Tamarix: a case study of ecological change in the American West. Oxford University Press, New York, New York, USA.

Douglass, C. H., S. J. Nissen, P. J. Meiman, and A. R. Kniss. 2016. Impacts of imazapyr and triclopyr soil residues on the growth of several restoration species. Rangeland Ecology and Management 69:199-205.

Drus, G. M., T. L. Dudley, C. M. D’Antonio, T. J. Even, M. L. Brooks, and J. R. Matchett. 2014. Synergistic interactions between leaf beetle herbivory and fire enhance tamarisk (Tamarix spp.) mortality. Biological Control 77:29-40.

Friedman, J. M., G. T. Auble, P. B. Shafroth, M. L. Scott, M. F. Merigliano, M. D. Freehling, and E. R. Griffin. 2005. Dominance of non-native riparian trees in western USA. Biological Invasions 7:747-751.

Friesen, L. F., H. J. Beckie, S. I. Warwick, and R. C. Van Acker. 2009. The biology of Canadian weeds. 138. Kochia scoparia (L.) Schrad. Canadian Journal of Plant Science 89:141-167.

Gaskin, J. F. 2013. Genetics of Tamarix. Pages 21-28 in A. A. Sher and M. F. Quigley, editors. Tamarix: a case study of ecological change in the American West. Oxford University Press, New York, New York, USA.

Glenn, E. P., and P. L. Nagler. 2005. Comparative ecophysiology of Tamarix ramosissima and native trees in western U.S. riparian zones. Journal of Arid Environments 61:419-446.

Graf, W. L. 2006. Downstream hydrologic and geomorphic effects of large dams on American rivers. Geomorphology 79:336-360.

Harms, R. S., and R. D. Hiebert. 2006. Vegetation response following invasive tamarisk (Tamarix spp.) removal and implications for riparian restoration. Restoration Ecology 14: 461-472.

Hobbs, R. J., and L. F. Huenneke. 1992. Disturbance, diversity, and invasion: implications for conservation. Conservation Biology 6:324-337.

Hudson, J. R., J. L. Hanula, and S. Horn. 2014. Impacts of removing Chinese privet from riparian forests on plant communities and tree growth five years later. Forest Ecology and Management 324:101-108.

Hultine, K. R., J. Belnap, C. Van Riper III, J. R. Ehleringer, P. E. Dennison, M. E. Lee, P. L. Nagler, K. A. Snyder, S. M. Uselman, and J. B. West. 2010. Tamarisk biocontrol in the western United States: ecological and societal implications. Frontiers in Ecology and the Environment 8:467-474

Hultine, K. R., T. L. Dudley, D. F. Koepke, D. W. Bean, E. P. Glenn, and A. M. Lambert. 2015. Patterns of herbivoryinduced mortality of a dominant non-native tree/shrub (Tamarix spp.) in a southwestern US watershed. Biological Invasions 17:1729-1742.

Jacobs, J., and K. Denny. 2006. Ecology and management of Russian knapweed (Acroptilon Repens (L.) DC). Invasive Species Technical Note No. MT-7. U.S. Department of 
Agriculture, Natural Resources Conservation 17 Service, Montana, USA.

Jaeger, K. L., and E. Wohl. 2011. Channel response in a semiarid stream to removal of tamarisk and Russian olive. Water Resources Research 47:W02536.

Johnson, W. C. 2002. Riparian vegetation diversity along regulated rivers: contribution of novel and relict habitats. Freshwater Biology 47:749-759.

Johnson, T. D. 2013. Tamarix: Passenger or driver of ecosystem change? Pages 256-266 in A. A. Sher and M. Quigley, editors. Tamarix: a case study of ecological change in the American West. Oxford University Press, New York, New York, USA.

Kennard, D., N. Louden, D. Gemoets, S. Ortega, E. González, D. Bean, P. Cunningham, T. Johnson, K. Rosen, and A. Stahlke. 2016. Tamarix dieback and vegetation patterns following release of the northern tamarisk beetle (Diorhabda carinulata) in Western Colorado. Biological Control 101: 114-122.

Kreyling, J., C. Beierkuhnlein, L. Ellis, and A. Jentsch. 2008. Invasibility of grassland and heath communities exposed to extreme weather events - additive effects of diversity resistance and fluctuating physical environment. Oikos 117:1542-1554.

Legendre, P., and E. D. Gallagher. 2001. Ecologically meaningful transformations for ordination of species data. Oecologia 129:271-280.

Liebert, R., J. Huntington, C. Morton, S. Sueki, and K. Acharya. 2016. Reduced evapotranspiration from leaf beetle induced tamarisk defoliation in the Lower Virgin River using satellite-based energy balance. Ecohydrology 9:179-193.

McDonald, A. K., B. P. Wilcox, G. W. Moore, C. R. Hart, Z. Sheng, and M. K. Owens. 2015. Tamarix transpiration along a semiarid river has negligible impact on water resources. Water Resources Research 51:5117-5127.

McShane, R. R., D. A. Auerbach, J. M. Friedman, G. T. Auble, P. B. Shafroth, M. F. Merigliano, M. L. Scott, and N. L. Poff. 2015. Distribution of invasive and native riparian woody plants across the western USA in relation to climate, river flow, floodplain geometry and patterns of introduction. Ecography 38:1254-1265.

Merritt, D. M. 2013. Reciprocal relations between riparian vegetation, fluvial landforms, and channel processes. Pages 219-243 in J. F. Shroder, Editor-in-chief, and E. Wohl, Volume Editor. Treatise on geomorphology, Volume 9. Fluvial geomorphology. Academic Press, San Diego, California, USA.

Merritt, D. M., and D. J. Cooper. 2000. Riparian vegetation and channel change in response to river regulation: a comparative study of regulated and unregulated streams in the Green River Basin, USA. Regulated Rivers: Research and Management 16:543-564.

Merritt, D. M., and N. L. Poff. 2010. Shifting dominance of riparian Populus and Tamarix along gradients of flow alteration in western North American rivers. Ecological Applications 20:135-152.

Merritt, D. M., and P. B. Shafroth. 2012. Edaphic, salinity, and stand structural trends in chronosequences of native and non-native dominated riparian forests along the Colorado River, USA. Biological Invasions 14:2665-2685.

Nagler, P. L., T. Brown, K. R. Hultine, C. Van Riper III, D. W. Bean, P. E. Dennison, R. S. Murray, and E. P. Glenn. 2012. Regional scale impacts of Tamarix leaf beetles (Diorhabda carinulata) on the water availability of western U.S. rivers as determined by multi-scale remote sensing methods. Remote Sensing of Environment 118:227-240.

Nagler, P. L., K. Morino, K. Didan, J. Erker, J. Osterberg, K. R. Hultine, and E. P. Glenn. 2009. Wide-area estimates of saltcedar (Tamarix spp.) evapotranspiration on the lower Colorado
River measured by heat balance and remote sensing methods. Ecohydrology 2:18-33.

Nagler, P. L., S. Pearlstein, E. P. Glenn, T. B. Brown, H. L. Bateman, D. W. Bean, and K. R. Hultine. 2014. Rapid dispersal of saltcedar (Tamarix spp.) biocontrol beetles (Diorhabda carinulata) on a desert river detected by phenocams, MODIS imagery and ground observations. Remote Sensing of Environment 140:206-219.

Nagler, P. L., P. B. Shafroth, J. W. LaBaugh, K. A. Snyder, R. L. Scott, D. M. Merritt, and J. Osterberg. 2010. The potential for water savings through the control of saltcedar and Russian olive. Pages 33-48 in P. B. Shafroth, C. A. Brown, and D. M. Merritt, editors. Saltcedar and Russian olive control demonstration act science assessment. U.S. Geological Survey Scientific Investigations Report 2009-5247. U.S. Department of the Interior, U.S. Geological Survey, Reston, Virginia, USA.

Ohrtman, M. K., A. A. Sher, and K. D. Lair. 2012. Quantifying soil salinity in areas invaded by Tamarix spp. Journal of Arid Environments 85:114-121.

Oksanen, J., F. G. Blanchet, R. Kindt, P. Legendre, P. R. Minchin, R. B. O'Hara, G. L. Simpson, P. Solymos, M. H. H. Stevens, and H. Wagner. 2013. Vegan: community ecology package. R package version 2.0-10. http://CRAN.R-project. org $/$ package $=$ vegan

Orr, C. H., and S. Koenig. 2006. Planting and vegetation recovery on exposed mud flats following two dam removals in Wisconsin. Ecological Restoration 24:79-86.

Ostoja, S., M. L. Brooks, T. Dudley, and S. R. Lee. 2014. Shortterm vegetation response following mechanical control of saltcedar (Tamarix spp.) on the Virgin River, Nevada, USA. Invasive Plant Science and Management 7:310-319.

Palmer, M. A., C. A. Reidy Liermann, C. Nilsson, M. Flörke, J. Alcamo, P. S. Lake, and N. Bond. 2008. Climate change and the world's river basins: anticipating management options. Frontiers in Ecology and the Environment 6:81-89.

Pattison, R. R., C. M. D'Antonio, T. L. Dudley, K. K. Allander, and B. Rice. 2011. Early impacts of biological control on canopy cover and water use of the invasive saltcedar tree (Tamarix spp.) in western Nevada, USA. Oecologia 165: 605-616.

Pearson, D. E., Y. K. Ortega, J. B. Runyon, and J. L. Butler. 2016. Secondary invasion: The bane of weed management. Biological Conservation 197:8-17.

Perry, L. G., L. V. Reynolds, T. J. Beechie, M. J. Collins, and P. B. Shafroth. 2015. Incorporating climate change projections into riparian restoration planning and design. Ecohydrology 8:863-879.

Pinheiro, J. C., D. M. Bates, S. DebRoy, D. Sarkar, and R Development Core Team. 2007. nlme: linear and nonlinear mixed effect models. R package version 3.1-86. www.r-project. org

Planty-Tabacchi, A. M., E. Tabacchi, R. J. Naiman, C. Deferrari, and H. Décamps. 1996. Invasibility of species-rich communities in riparian zones. Conservation Biology 10:598-607.

Primiani, M. M., J. C. Cotterman, and L. L. Saari. 1990. Resistance of kochia (Kochia scoparia) to sulfonylurea and imidazolinone herbicides. Weed Technology 4:169-172.

R Core Team. 2016. R: a language and environment for statistical computing. R Foundation for Statistical Computing, Vienna, Austria. http://www.R-project.org/

Reynolds, L. V., and D. J. Cooper. 2011. Ecosystem response to removal of exotic riparian shrubs and a transition to upland vegetation. Plant Ecology 212:1243-1261.

Reynolds, L. V., P. B. Shafroth, and P. K. House. 2013. Abandoned floodplain plant communities along a regulated dryland river. River Research and Applications 30:1084-1098. 
Richardson, D. M., P. M. Holmes, K. J. Esler, S. M. Galatowitsch, J. C. Stromberg, S. P. Kirkman, P. Pysek, and R. J. Hobbs. 2007. Riparian vegetation: degradation, alien plant invasions, and restoration prospects. Diversity and Distributions 13:126-139.

Rowland, D. L., A. A. Sher, and D. L. Marshall. 2004. Interand intra-population variation in seedling performance of Rio Grande cottonwood under low and high salinity. Canadian Journal of Forest Research 34:1458-1466.

Shafroth, P. B., V. B. Beauchamp, M. K. Briggs, K. Lair, M. L. Scott, and A. A. Sher. 2008. Planning riparian restoration in the context of Tamarix control in Western North America. Restoration Ecology 16:97-112.

Shafroth, P. B., and M. K. Briggs. 2008. Restoration ecology and invasive riparian plants: an introduction to the special section on Tamarix spp. in Western North America. Restoration Ecology 16:94-96.

Shafroth, P. B., J. R. Cleverly, T. L. Dudley, J. P. Taylor, C. Van Riper III, E. P. Weeks, and J. N. Stuart. 2005. Control of Tamarix in the western United States: implications for water salvage, wildlife use, and riparian restoration. Environmental Management 35:231-246.

Shafroth, P. B., D. M. Merritt, M. K. Briggs, V. B. Beauchamp, K. D. Lair, M. L. Scott, and A. A. Sher. 2013. Riparian restoration in the context of Tamarix control. Pages 404-425 in A. A. Sher and M. Quigley, editors. Tamarix: a case study of ecological change in the American West. Oxford University Press, New York, New York, USA.

Sher, A. A. 2013. The future of Tamarix in North America. Pages 441-458 in A. A. Sher and M. Quigley, editors. Tamarix: a case study of ecological change in the American West. Oxford University Press, New York, New York, USA.

Sher, A. A., S. Gieck, C. S. Brown, and S. J. Nissen. 2008. Firstyear responses of cheatgrass following Tamarix spp. control and restoration-related disturbances. Restoration Ecology 16:129-135.

Sher, A. A., A. Henry, and E. González. 2015. Plant community response to riparian invasive tree removal by biocontrol vs. active means for 40 sites over five years. Ecological Society of America 100th Annual Conference. Baltimore, Maryland, USA.

Sher, A. A., and L. A. Hyatt. 1999. The disturbed resource-flux invasion matrix: a new framework for patterns of plant invasion. Biological Invasions 1:107-114.
Sher, A. A., and D. L. Marshall. 2003. Ecology-seedling competition between native Populus deltoides (Salicaceae) and exotic Tamarix ramosissima (Tamaricaceae) across water regimes and substrate type. American Journal of Botany 90:413-422.

Sher, A. A., D. L. Marshall, and J. P. Taylor. 2002. Establishment patterns of native Populus and Salix in the presence of invasive nonnative Tamarix. Ecological Applications 12:760-772.

Sherry, R. A., P. B. Shafroth, J. Belnap, S. Ostoja, and S. C. Reed. 2016. Germination and growth of native and invasive plants on soil associated with biological control of tamarisk (Tamarix spp.). Invasive Plant Science and Management 9:290-307.

Stromberg, J. C. 1997. Growth and survivorship of Fremont cottonwood, Goodding willow, and salt cedar seedlings after large floods in central Arizona. Great Basin Naturalist 57:198-208.

Stromberg, J. C. 2001. Restoration of riparian vegetation in the south-western United States: importance of flow regimes and fluvial dynamism. Journal of Arid Environments 49:17-34.

Stromberg, J. C., S. J. Lite, R. Marler, C. Paradzick, P. B. Shafroth, D. Shorrock, J. M. White, and M. S. White. 2007. Altered stream-flow regimes and invasive plant species: the Tamarix case. Global Ecology and Biogeography 16:381-393.

Sueki, S., K. Acharya, J. Huntington, R. Liebert, J. Healey, R. Jasoni, and M. Young. 2015. Defoliation effects of Diorhabda carinulata on tamarisk evapotranspiration and groundwater levels. Ecohydrology 8:1560-1571.

Tamarisk Coalition. 2016. 2007-2015 Tamarisk beetle distribution map. http://www.tamariskcoalition.org/programs/tama risk-beetle-maps

Tockner, K., and J. A. Stanford. 2002. Riverine flood plains: present state and future trends. Environmental Conservation 29:308-330.

USDA-NRCS (U.S. Department of Agriculture-Natural Resources Conservation Service). 2014. The PLANTS database. http://plants.usda.gov

Vincent, K. R., J. M. Friedman, and E. R. Griffin. 2009. Erosional consequence of saltcedar control. Environmental Management 44:218-227.

Zavaleta, E. 2013. Evapotranspiration by tamarisk in the Colorado River Basin. Pages 44-62 in A. A. Sher and M. Quigley, editors. Tamarix: a case study of ecological change in the American West. Oxford University Press, New York, New York, USA.

\section{SUPPORTING INFORMATION}

Additional supporting information may be found online at: http://onlinelibrary.wiley.com/doi/10.1002/eap.1566/full

Data Availability

Data associated with this paper have been deposited in a Dryad digital repository https://doi.org/10.5061/dryad.70mt1 